志賀

岩本静男 [神奈川大学工学部建築学科 助教授・工博] 本報告は，温水式床暖房に扔ける放熱面に着目し，床面内に埋め 込まれる温水配管に中空パイプをわたして放熱を図るシステムにつ いて, 荎内への放熱特性を仔細に検討している。実験結果からは, 定常時においても，暖房開始時の立ち上がりにおいても，従来型と ほぼ同程度であることが示されている。温水配管径を大きくしかつ 配管長を短くできることから，搬送動力を抑えられるため一層の省 エネルギーが期待できる。今後の課題として実際の住宅に用いた場 合の性能把握が必要であろう。例之ば，本報告で得られたような放 熱特性が期待できるか，床表面温度は在来型と比較して同程度に抑 えられるか, 床表面温度の分布はどの程度か, 搬送動力削減による 省エネルギーの効果はどの程度か，などが挙げられる。また暖房開 始時のみならず暖房時の制御性能も検討が必要であろう。実測実験 などによる検討が期待される。
均, 水沼 信, 浜砂ひとみ, 大内裕子, 福代和宏, 中園買人 189

龍 有二[北九州市立大学国際環境工学部環境空間デザイシ学科 教授・工博]

温水式床暖房システムの循環パイプ側の技術開発を目的として, 中空パイプを既存の温水式床暖房に導入する新システムを考案し, その放熱性能実験についてまとめたものである。具体的な提案シス テムは, 従来の温水循環パイプの大部分を循環パイプ間に等間隔に 接続した銅製の中空パイプで代用することにより，温水循環パイプ の敷設長さを大幅に短縮するという非常にユニークなものである。 本報告は, 人工気象室での試験体放熱実験により, システム設計お よび運転時に必要となる基本的放熱性能を把握するとともに, 本シ ステムが, 市販の標準的な温水床暖房と同等の放熱性能を有するこ とを明らかにしており，実用上価值のある有用な情報を提供するも のである。立ち上がり時間の短縮化や床表面における温度ムラの解 消などの課題はあるものの, 敷設工期の短縮化, イニシャルコスト の低減，ボイラー負荷の軽減などが見込まれ，今後の実用化に向け た展開が期待される。

\title{
軽量・薄層型屋上緑化技術のヒートアイランド緩和効果の定量評価に関する研究
}

三坂育正, 石井康一郎, 横山 仁, 山口隆子, 成田健一 195

尾島俊雄 [早稲田大学理工学部建築学科 教授・工博] 東京都がヒートアイランド対策の一環として，2001 年, 屋上緑化 を義務づけたことはよいとして, 屋上緑化の効果が問題になってい た。日本学術会議のヒ一トアイランド現象研連の調查によれば，平 成 15 年度の国の「七一トアイランド対策に資する各省施策と施策 費」は 2 兆 6 千億円，地方自治体の予算が 490 億円も計上されてい る。東京都の屋上緑化費用は公共投資には含まれないものの, 七一 トアイランドのためと称して民間投資が義務づけられていることに 対して，その投資効果に疑問をもつ者が多い。特に屋上緑化は建設 費のみならず，維持管理が容易でないため，その効果に関する科学 的データを求める声が強く，この問題に直接答えた点を評価する。 具体的に，ヒートアイランド緩和効果が少ないのではと考えられて いたセダムは予定通り芝やイワダレソウに比べて逆効果ですらある ことを明らかにしただけでも評価に値する。願わくば，技術報告集 の読者にとってもっと使いやすい設計資料にまでまとめて報告して 欲しかった。
萩島 理 [九州大学総合理工学研究院 助教授・工博] 屋上緑化のヒートアイランド緩和効果を定量的に論じる為には, 蒸発効薪の観測デー夕は極めて重要である。これに対し本稿は, 観 測に基づき複数の緑化システムに対し顕熱・潜熱フラックスを定量 化し熱収支構造を明らかにした貴重なものである。特に散水条件に よりセダムの植物生理の変化が生じ蒸発効率が大きく低下する事を 示した Fig-8 は屋上緑化の夕イプによるヒートアイランド緩和効果 の違いを把握する上で有効である。小型試験体の重量から潜熱 ラックスを推定，さらに残差として顕熱フラックスを推定する手法 については,顕熱フラックス(Fig-6) と表面温度と気温の温度差 (Fig -5）の正負が一致していない時間帯があることから若干の誤差を有 すると推察される。この誤差の要因に関してもう少し言及なされて おれば, 本稿の手法は屋上緑化性能評価の標潐手法としての説得力 が増したと思われる。
持田 灯 [東北大学大学院工学研究科都市・建築学専攻 助教授・工博] 本研究は観測デー夕を用いて大阪における海風の効果を詳しく調 べ, 都市の環境計画のための貴重なデー夕を提供している。「昼間の 気温に対しては，海風の影響が支配的であり，都市化による影響は 顕著には表れない」という結果は明快である。最近, 評者等も東北 の地方都市における実測, 解析から同様の結論を得ているが, 遥か に排熱密度が高く, 都市化の進んでいる大阪の日中の気温を決定す る要因について,「都市化による影響は顕著には表れない」と明快に 言ってしまっていいのか心配にになった。確かに，図 7-a〜7-dにお いて, 最高気温と人工排熱量, 自然被覆率等のパラメータには明確 な相関は見られないが，測定点の状況によりいくつかのグループに 分ければ，何らかの相関を見いだせないであろうか？「大阪で日中 の気温を下げたい場合, 緑化等しても仕方ない」とも取られかねな い結論であり，さらなる検討を期待したい。

\section{吉田篤正 [大阪府立大学大学院工学研究科} 機械系専攻エネルギー一機械工学分野 教授・工博] 都市で観測されるヒートアイランド現象は，エネルギーや熱環境 の問題としてマスコミで取り上げられ，一般市民の力及にも認知さ れるようになってきました。これまでにも実測や数值解析などによ る報告が多数なされています。日本の場合, 多くの都市が海岸沿い に立地するため，海陸風循環の影響を強く受けることになります。 本論文で取り上げている都市の熱環境と海風の関係を明らかにする ことは重要であると考えます。都市の熱環境改善が叫ばれ，その対 策メ二ューも数多く提案されています。その中で風通しは検討すべ き課題であり，海風の導大，活用も考之ていくべきでしょう。昼間 と夜間で都市の気温に影響を与える因子が異なり，昼間は海風の影 響が強いとする結論は納得できます。海風の強さに都市の気温が影 響を与えている可能性もあり, 都市に対する海風の泠却能力の評価, 海風の活用方法についても議論していただければと思います。 